\title{
Expanded Contents List
}

Abbreviations

ix

Introduction 1

Žižek and Politics 1

So Who is Slavoj Žižek?

The Dilemmas of Enjoyment as a Political Factor 7

A Critical Introduction $\quad 14$

Our Method: Žižek and Political Philosophy 17

Reading Žižek: The Politics of Žižek's Style 20

The Two Žižeks $\quad 24$

Part One. Žižek

1 Žižek and the Radical-Democratic Critique of Ideology 31 Looking Ahead 31

Slavoj Žižek and the New World Order 31

The Spirit is a Bone, Globalisation is Fundamentalism $\quad 35$

From Hegel to Psychoanalysis $\quad 41$

Ideological Identification and its Vicissitudes 44

Ideological Fantasy: The Others Supposed to Believe and Enjoy 53

2 Retrieving the Subject: Žižek's Theoretical Politics 60

Introduction: Žižek's Ticklish Subject 60

Žižek's Criticism of 'Post-Structuralism' 64

Changing the (Cartesian) Subject: Cogito, not Sum 74

From the Sublime to the Subject, Aesthetics to Politics 77

The Substance is Subject: The Inner Hegelian Kernel

of Žižek's Dialectics

79

Counting Ourselves in: Žižek's Hegel $\quad 80$

Concluding: The Subject of Politics 81 
3 Did Žižek Say Democracy? $\quad 86$

Placing Žižek's Typology of Different Regimes $\quad 86$

Revolution, Quarter or Half Turn? $\quad 89$

Challenging 'Totalitarianism' 94

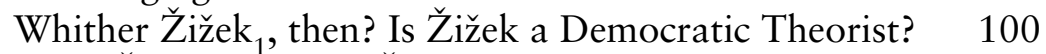

From Žižek ${ }_{1}$ towards Žižek

Inter-chapter. Žižek's Vanishing Mediation 112

The Turn to Schelling: Žižek's Vanishing Mediations 112

God as Subject; the Subject as a God: Žižek's Schelling 117

The Paratactic View: What's God to Žižek's Political

Philosophy? 119

Žižek's Embrace of Schelling's Identical Subject-Object 123

Political Theology and the Subject-Object 127

What is Capitalism? Žižek's Evasion of Economics 131

Part Two. Žižek

4 Postmodernity and the Society of Generalised Perversion 139

Introduction 139

Reflexive Modernity $\quad 141$

Pathological Narcissism $\quad 144$

Ambivalent Diagnosis 146

Superego Enjoyment and Generalised Psychosis? 152

The Decline of Symbolic Authority and Generalised

Perversion 155

Generalised Perversion and Commodity Fetishism 159

Some Theoretical and Cultural Concerns 162

5 Žižek’s Vanguard Politics $\quad 165$

A Paradoxical View 165

Post-Politics in the Age of Generalised Perversion $\quad 166$

So What was Politics Proper? 170

The Theoretical Left and its Disavowals 172

Žižek's Push towards the Act 180

After the Act, or Repeating Sorel? No Thanks! 188

6 Religion and the Politics of Universal Truth 194

Why Political Theology? 194

Introducing Democratic Fundamentalism 197 
Into the Heart of Darkness: Žižek's Romantic

Dalliance with Orthodoxy

Love thy Neighbour? Yes Please! Žižek's Participatory Christianity

204

Nasty, Brutish and Short: Meet the Neighbours

210

Repeating Hobbes: The Vanishing Other and the Authoritarian Solution

Conclusion

Quilting Points

219

To Anticipate

223

Repeating Lenin, an Infantile Disorder?

225

For Multi-Dimensional Political Theory

228

References

234

Index

249 